\title{
Transcriptional Profile of Helicobacter pylori Virulence Genes in Patients with Gastritis and Gastric Cancer
}

\author{
Manouchehr Ahmadi Hedayati $\mathbb{D}^{1,2}$ and Saeed Salavati ${ }^{2,3}$ \\ ${ }^{1}$ Liver and Digestive Research Center, Research Institute for Health Development, Kurdistan University of Medical Sciences, \\ Sanandaj, Iran \\ ${ }^{2}$ Department of Microbiology, Faculty of Medicine, Kurdistan University of Medical Sciences, Sanandaj, Iran \\ ${ }^{3}$ Student Research Committee, Kurdistan University of Medical Sciences, Sanandaj, Iran \\ Correspondence should be addressed to Manouchehr Ahmadi Hedayati; dr.ahmadi2000@gmail.com
}

Received 5 February 2020; Revised 1 January 2021; Accepted 1 February 2021; Published 10 February 2021

Academic Editor: Mario Dell Agli

Copyright ( 2021 Manouchehr Ahmadi Hedayati and Saeed Salavati. This is an open access article distributed under the Creative Commons Attribution License, which permits unrestricted use, distribution, and reproduction in any medium, provided the original work is properly cited.

\begin{abstract}
Introduction. Numerous molecular epidemiology studies have been performed about the frequency of Helicobacter pylori virulence genes in patients with $H$. pylori infection so far. This study was conducted to detect transcriptional profile by cDNA of H. pylori virulence genes in gastric biopsy samples of gastritis and gastric carcinoma patients. Materials and Methods. In a casecontrol study, based on the prevalence of gastritis and gastric cancer in Sanandaj city during 2018 and 2019,23 and 11 gastric antral biopsy samples with $H$. pylori infection were collected from gastritis and gastric carcinoma patients by the consecutive and available sampling method. Pathological characters, including tumor grades and tumor areas for gastric carcinoma biopsy samples prepared from gastric cancer areas, were determined by the pathologist. Total RNA of gastric antral biopsy samples was extracted, and their cDNA was synthesized by TaKaRa kit. H. pylori virulence genes' cDNA using specific primers and PCR was detected. This study's results were analyzed by SPSS version 25 and statics chi-square tests for determination of relationship and correlation between cDNAs of $H$. pylori transcriptional profile and clinical outcomes of $H$. pylori infection, including gastritis, gastric carcinoma, tumor grades, and tumor area. Results. The positive statistical correlations were observed between transcripts of $c a g A$, cagA-EPIYAC, cagE, and cagY genes and $H$. pylori infection clinical outcomes $(P<0.05)$. Conclusion. Detection of the $H$. pylori virulence genes' $\mathrm{cDNA}$ in gastric biopsy samples can help provide the prognosis of clinical outcomes.
\end{abstract}

\section{Introduction}

Microbe factors, including toxins, enzymes, and structural antigens, induce the host's immune system [1]. The most common cause of human chronic infection is Helicobacter pylori, which is considered host-microbe interactions [2-4]. $H$. pylori chronic infection is followed by chronic mild gastritis with or without clinical manifestations, which progresses to gastric cancer in $1-2 \%$ of patients with $H$. pylori cagApositive genotypes infection [5]. The molecular epidemiology studies show a positive correlation between $H$. pylori virulence genes' frequency and the clinical outcomes $[6,7]$.
The results of previous studies show that the clinical outcomes are related to $H$. pylori virulence genes' expression. In parallel with host immunologic effects on gastritis progression, there are the effects of different ambient conditions on $H$. pylori virulence genes' expression in host cells [8-14]. As the relevant studies, salt and acidic $\mathrm{pH}$ change the transcription of the $H$. pylori virulence genes through the bacterial ARS two-components system $[9,13]$. Some studies have concluded that the $H$. pylori persistence infection is due to the antigenic phase variations in $H$. pylori outer membrane proteins, including Hop, Bab, Sab, Oip, Dup, and Alp proteins [15-20]. 
In the early stages of $H$. pylori infection, Bab adhesin attaches to Lewis B antigens located on gastric epithelial cells' surface by a tight attachment between the bacterial type 4 secretory system and gastric epithelial cells [20]. The babA2 gene, with $60 \%$ frequency, encodes bab adhesin in H. pylori strains related to gastric cancer [21].

Besides, the persistence infection is stabilized by attaching Sab antigens to sialyl-Lewis $\mathrm{x}$ receptors on gastric epithelial cells $[17,18]$. The previous studies show a high frequency of $s a b$ genes among $H$. pylori strains related to severe clinical manifestations [22].

Alp adhesin of $H$. pylori involves proinflammatory signals in gastric mucosal epithelial cells by attaching to type IV collagen and laminin on gastric epithelial cells (GECs) and activation of MAPK and NFKB cell signaling pathways [23]. The results of relevant studies show that all clinical H. pylori strains express the alpA/B gene [24].

Like Alp adhesin, Oip adhesin in the company with the type 4 secretory system contributes to bacterial colonization and inflammation by increasing IL- 8 production $[25,26]$. The upregulation of the oip gene induces apoptosis and changes in the GECs cytoskeleton, causing severe clinical manifestations, including gastric cancer [22]. Molecular epidemiology studies show a frequency of oip gene expression up to $70 \%$ among $H$. pylori clinical strains [25].

$H$. pylori vacuolating cytotoxin A pierces the mitochondrial cytoplasmic membrane and activates the apoptosis cell signaling in GECs [13-15]. H. pylori vacA gene sequence is involved in the $s, \mathrm{i}$, and $m$ variable regions that show statistical correlations with clinical outcomes of H. pylori infection and geographical distribution [27]. The vacA gene regularly expresses because it is located adjacent to the 16s rRNA conserved gene area [13]. Some studies show that vacA gene expression is induced after $H$. pylori colonization on GECs, and fluctuations in vacA gene expression rate among $H$. pylori clinical strains can be expectable $[28,29]$.

The cag pathogenicity island consists of 31 genes that express type 4 secretory system (T4SS) proteins [30, 31]. The T4SS conducts the injection of CagA (cytotoxin-associated gene A) protein into GECs $[30,31]$. The CagA protein induces GECs proliferation through JAK/STAT3 and MAPK kinases pathways [30]. The surface connecting complex of T4SS has been comprised of CagY, CagL, CagI, CagC, and $\mathrm{CagH}$ proteins [30]. The a5 $\beta 1$ integrin receptor on the gastric epithelial cells is the ligand of CagY protein [32]. The results of relevant studies show a few variable regions with high recombination tendency in the cagY gene [33]. The recombination between forward and middle repeated sequences of the cagY gene changes its expression and, consequently, the cagY protein's affinity to integrin receptors [32]. CagY protein contacts GECs receptors and changes the host mucosal immune response's balance toward reducing mucosal immune and progression of the $H$. pylori persistent infection [32]. The previous studies show that cagY gene expression is regulated separately from other cag pathogenic island genes $[33,34]$. The results of relevant studies state the modulation role of CagY protein in the GECs immune system in the progression of an $H$. pylori active chronic infection [32-35]. The previous studies show the positive correlations between CagT and CagE proteins and the $H$. pylori pathogenicity $[36,37]$. CagE, as an NTPase enzyme, involves the secretion of cagA [30]. CagT, as a lipoprotein, connects the T4SS core proteins complex to the bacterial outer membrane [30]. Both CagT and cagE are essential for the injection of CagA into GECs [30].

Various molecular mechanisms of gene expression control have been shown in $H$. pylori. The detection of bacterial virulence genes alone does not indicate genes' permanent expression [24-28]. In this regard, sab gene expression changes by turning on and off an operator called the switching mechanism [24]. The slipped-strand repair mechanism controls oip $A$ gene expression through repetitive CT sequences at the promotor's $5^{\prime}$ end $[22,23]$. hopZ gene has a repeat sequence in the signaling region that shows high recombination frequency and antigenic phase changes [38]. The changes in the stomach acidity flow and the constant contact of $H$. pylori to the gastric epithelial cells increase the expression of H. pylori adhesin's genes such as hopZ [38]. These statements mean that microbe and host interaction depends on ambient variations on microbes' virulence genes expression.

In the current study, we surveyed $H$. pylori virulence genes' transcript profile and their relation with clinical outcomes by detecting cDNAs in gastric antral biopsy samples collected from gastritis and gastric cancer patients $H$. pylori infection referred to hospitals of Sanandaj city.

\section{Methods}

Cochran's statistical formula was used in a case-control study to determine the number of required samples based on gastritis and gastric cancer patients' prevalence in Sanandaj city [39]. Accordingly, 50 gastritis (control group) and 30 gastric carcinoma biopsy samples (case group) were collected by the consecutive and available sampling method from patients referred to Tohid and Shaheed Ghazi hospitals in Sanandaj city for 18 months from September 2018 to March 2019. 23 (46\%) and 11 (66.36\%) patients had been infected with $H$. pylori in gastritis and gastric carcinoma patients, respectively. After obtaining ethical consent for publishing research results without patient details, data of geography for each patient, including age, sex, and results of a urea breath test for rapid diagnosis of $H$. pylori infection, were recorded in questionnaire forms. The exclusion criteria included the patients with chemotherapy against $H$. pylori infection, smoking, and alcohol consumption to eliminate study interventions. Endoscopic observations of gastroenterologists diagnosed gastritis and gastric carcinoma. The histological and pathological characters' data for gastric carcinoma samples were collected from the Pathology Laboratory of Tohid Hospital in Sanandaj city. According to the manufacturer's RNALater solution protocol, a gastric antral biopsy sample was obtained from each gastritis and gastric cancer patient with $H$. pylori infection to detect cDNAs of $H$. pylori virulence genes by using the PCR method. Gastric antral biopsy samples were dropped into RNALater solution (Roche Co., Germany) immediately. The 
total RNA of biopsy samples was extracted according to the manufacturer's protocol (all in one mini preps kit, Bio Basic Canada Inc.). The $28 \mathrm{~S}$ and $18 \mathrm{~S}$ rRNA bands had evaluated the RNA integrity on an agarose gel at a concentration of $1.2 \%$. The absorbance ratio at $260 \mathrm{~nm}$ and $280 \mathrm{~nm}$ was assessed for the purity of RNA by the NanoDrop ${ }^{\circledR} 2000$ spectrophotometer machine (Thermo Fisher Company, Germany). Total RNA was stored at -70 degree centigrade. At the next step, according to the manufacturer's protocol of PrimeScriptTM RT reagent Kit (TaKaRa Co.), total RNA was converted to cDNA. To assess cDNAs' purity, PCR was performed using $H$. pylori 16s rRNA-specific primers; then, PCR products were run on agarose gel $1.5 \%$. Forward and reverse specific primers for detecting $H$. pylori virulence genes' cDNA were designed using Primer3 online software (version 0.4 .0 ). Table 1 shows the characteristics of all used specific primers in this study that include the sequence of primers, annealing temperature, and product size. The cDNAs of $H$. pylori virulence genes were detected using the gradient thermocycler PCR machine (BioRad Company, Germany). PCR master mix included buffer $10 \mathrm{x}$ (2.5 microlitres), DNA Taq polymerase $5 \mathrm{U} /$ microliter $(0.25$ microlitres), dNTPs $10 \mathrm{mM}$ (0.5 microlitres), $\mathrm{MgCl}_{2} 50 \mathrm{mM}$ (1 microlitre), cDNA (2 microlitres), forward and reverse specific primers 10 picoliters (each one 0.5 microlitres), and RNase-free water (17.75 microlitres) in final volume 25 microlitres. The thermal cycling PCR steps were involved an initial denaturation at $94^{\circ} \mathrm{C}$ for 5 minutes, a denaturation at $94^{\circ} \mathrm{C}$ for 30 seconds, a primer annealing for 45 seconds (primers temperatures have been shown in Table 1), an extension at $72^{\circ} \mathrm{C}$ for 45 seconds, and a final extension at $72^{\circ} \mathrm{C}$ for 5 minutes [27]. The denaturation through the extension step was repeated for 30-35 cycles. The PCR products of $H$. pylori virulence genes' cDNA were run on $1.5 \%$ agarose gel. The results were analyzed using SPSS software version 25 and statics chi-square tests. We used the exact Fisher static test and confidence interval 95\% to analyze subgroups with a few numbers.

\section{Results}

3.1. Demographic Characteristics of Patients. Table 2 shows the demographic data of patients. The static results did not show any significant difference between disease (gastric and gastric cancer) and $H$. pylori infection $(P=0.487)$. As the same result, there was no significant static correlation between $H$. pylori infection and sexuality of patients $(P=0.518)$. However, there was a robust static correlation in the prevalence of gastric carcinoma in men $(P=0.005)$. The frequency of gastric carcinoma in men was four times rather than in women (Table 2). The highest and lowest $H$. pylori infection frequency was $61-73$ and $18-30$ years old, with $11(32.4 \%)$ and $2(5.9 \%)$ patients (Table 3$)$. These results show that there is no significant correlation statistically between $H$. pylori infection and patients' age $(P=0.314)$. On the other hand, there was a robust static correlation between gastric carcinoma and patients' age $(P=0.000)$ (Table 2$)$. Like the other similar study, increasing age in patients' populations increases gastric carcinoma frequency.
3.2. Transcription Profile of $H$. pylori Virulence Genes. Molecular detection of $H$. pylori infection in gastric biopsy samples was detected using the PCR method and 16s rRNAspecific primers. The vacA s2 gene's partial cDNA was sequenced (Bioneer Company, South Korea) and registered in GenBank with accession number MK642592.1 to confirm the PCR result. Table 4 shows $H$. pylori virulence genes' cDNA's frequency in biopsy samples of gastritis and gastric carcinoma patients with $H$. pylori infection. The frequency of $H$. pylori virulence genes' cDNA in gastric biopsy samples was different. Except for the cagT gene's cDNA, the frequency of cag pathogenicity island gene's cDNA including $\operatorname{cag} A, \operatorname{cag} A-E P I Y A C, \operatorname{cag} Y$, and $\operatorname{cagE}$ genes had a significant difference statistically with gastritis and gastric carcinoma and $H$. pylori infection (Table 4). The remarkable result was the low frequency of cagA gene's cDNA (4.35\%) in biopsy samples of gastritis patients. In contrast, the cagA gene's cDNA frequency was $45.5 \%$ in patients with gastric carcinoma. $52.2 \%$ of gastritis biopsy samples with $H$. pylori infection had cagT gene's cDNA (cagT ${ }^{+}$cDNA) $(P=0.001)$ (Table 4 ). In contrast, $36.4 \%$ of gastric carcinoma biopsy samples with $H$. pylori infection had simultaneous $\operatorname{cag} A$, cagT, cagY, and cagE genes' cDNA $\left(\operatorname{cag} A^{+} / \operatorname{cag} T^{+} / \operatorname{cagY}^{+} /\right.$ cagE $E^{+}$cDNA) $(P=0.001)$. Transcript profile of $H$. pylori outer membrane adhesin's genes showed that the frequency of $s a b$ and hop genes' cDNA was different between gastric biopsy samples of gastritis and gastric carcinoma patients. However, this difference was not significant, with an error level of 0.05 (Table 3). Our results show there was not any significant difference statistically in the frequency of vacAs $1 \mathrm{~m} 1 / \mathrm{s} 1 \mathrm{~m} 2$, oip $A$, alp $A / B$, and $I c e A 1 / 2$ genes' cDNA in two groups of patients with gastritis and gastric carcinoma that had H. pylori infection (Table 3 ).

\subsection{Correlation of H. pylori Virulence Genes' Expression.} The results of Spearman's statistic test showed the low positive correlations between the frequency of $b a b$ genes' cDNAs (babA2 and $b a b B)$ and other genes including $c a g A$, cagA-EPIYAC, sab, hopQ, and alp genes' cDNAs in gastric biopsy samples (correlations coefficients 0.428, 0.343, 0.435, 0.462 , and 0.397 with $P=0.012,0.047,0.01,0.02$, and 0.006 , respectively). There were the low positive correlation coefficients 0.357 and 0.362 (Spearman's static test) between the frequency of the hopQ gene's cDNA (hopQI and hopQII) and the frequency of $\operatorname{cag} A$ and $c a g E$ genes' cDNA in gastric biopsy samples, respectively $(P=0.038$ and 0.035 , respectively). There was a negative correlation coefficient -0.344 (Spearman's static test) between the frequency of sab gene's cDNA ( $s a b A$ and $s a b B)$ and the frequency of $v a c A s 1 \mathrm{~m} 2$ gene's cDNA $(P=0.046)$. There were positive correlation coefficients $0.432,0.460,0.460,0.440$, and 0.406 (Spearman's static test) between the frequency of $s a b$ gene's cDNA ( $s a b A$ and $s a b B$ ) and frequency of cagA, cagA-EPIYAC, cagE, alp, and oip genes' cDNA in gastric biopsy samples $(P=0.011$, $0.006,0.006,0.009$, and 0.017 , respectively). Our study showed that the alpA/B gene's cDNA's frequency had only a positive correlation of 0.440 with the frequency of $s a b$ gene's cDNA in gastric biopsy samples $(P=0.009)$. In sum, these 
Table 1: Primers used in this study.

\begin{tabular}{|c|c|c|c|c|}
\hline Specific primers & Sequence & Annealing $\mathrm{Tm},{ }^{\circ} \mathrm{C}$ & Product size, bp & Reference \\
\hline 16s rDNA $H$. pylori $\mathrm{F}$ & CTGGAGAGACTAAGCCCTCC & \multirow{2}{*}{50} & \multirow{2}{*}{446} & \multirow{2}{*}{ This study } \\
\hline 16s rDNA $H$. pylori $\mathrm{R}$ & AGGATCAAGGTTTAAGGATT & & & \\
\hline $\operatorname{cag} A \mathrm{~F}$ & TGACCAACAACCACAAACCG & \multirow{2}{*}{57} & \multirow{2}{*}{108} & \multirow{2}{*}{ This study } \\
\hline cagA $\mathrm{R}$ & TCAGGATCGTATGAAGCGACAG & & & \\
\hline $\operatorname{cag} A$ EPIYA-C F & AAGAAAGCAGGACAAGCAGC & \multirow{2}{*}{55} & \multirow{2}{*}{188} & \multirow{2}{*}{ This study } \\
\hline $\operatorname{cag} A$ EPIYA-C R & CTAACCGATCGCCCTACCTT & & & \\
\hline $\operatorname{cag} T \mathrm{~F}$ & AGGGTGTGGTGATGATAGCG & \multirow{2}{*}{55} & \multirow{2}{*}{154} & \multirow{2}{*}{ This study } \\
\hline $\operatorname{cag} T \mathrm{R}$ & TGCTTGTTGTTTGCTCCACT & & & \\
\hline $\operatorname{cag} E \mathrm{~F}$ & GAATGGAGCGAGCGATGAAA & \multirow[b]{2}{*}{56} & \multirow{2}{*}{163} & \multirow{2}{*}{ This study } \\
\hline cagE $\mathrm{R}$ & TAGGAATTTGCAGCGCTCAC & & & \\
\hline $\operatorname{cag} Y \mathrm{~F}$ & AGTTCAAGTGGCGCTAGATTG & \multirow{2}{*}{57} & \multirow{2}{*}{200} & \multirow{2}{*}{ This study } \\
\hline $\operatorname{cag} Y \mathrm{R}$ & ACAAGCCTTTCAAGCATTCGT & & & \\
\hline vacA s1/s2 F & ATGGAAATACAACAAACACAC & \multirow[b]{2}{*}{55} & \multirow[b]{2}{*}{$259 / 286$} & \multirow{2}{*}{ Atherton et al. [40] } \\
\hline$v a c A \mathrm{~s} 1 / \mathrm{s} 2 \mathrm{R}$ & CTGCTTGAATGCGCCAAAC & & & \\
\hline$v a c A \mathrm{~m} 1 / \mathrm{m} 2 \mathrm{~F}$ & TGGATAGTGCGACTGGGTTT & \multirow[b]{2}{*}{54} & \multirow{2}{*}{$205 / 220$} & \multirow{2}{*}{ This study } \\
\hline$v a c A \mathrm{~m} 1 / \mathrm{m} 2 \mathrm{R}$ & TCCATGCGGTTGTTGTTGTT & & & \\
\hline iceA1 F & GTGTTTTTAACCAAAGTATC & \multirow{2}{*}{45} & \multirow{2}{*}{247} & \multirow{2}{*}{ van Doorn et al. [41] } \\
\hline iceA1 R & CTATAGCCASTYTCTTTGCA & & & \\
\hline iceA2 F & GTTGGGTATATCACAATTTAT & & & \\
\hline iceA2 R & TTRCCCTATTTTCTAGTAGGT & 47 & $229 / 234$ & van Doorn et al. [41] \\
\hline hopQI F & ACGAACGCGCAAAAACTTTA & & & \\
\hline hopQI R & TTGCCATTCTCATCGGTGTA & 55 & 187 & Sicinschi et al. [42] \\
\hline hopQII F & ACAGCCACTCCAATCCAGAA & & & \\
\hline hopQII R & AACCCCACCGTGGATTTTAG & $5 b$ & 160 & Sicinsch1 et al. [42] \\
\hline$b a b A 2 \mathrm{~F}$ & CAATGCGGTGCGTGAAAATC & 57 & 205 & This studv \\
\hline babA2 R & ATACCCTGGCTCGTTGTTGA & 57 & 205 & This study \\
\hline$b a b B \mathrm{~F}$ & CAATTCCCCGGCGTATCAAG & & & \\
\hline$b a b B \mathrm{R}$ & ATTGCAAGTGATGGTCGTCG & 56 & 175 & This study \\
\hline$s a b A \mathrm{~F}$ & TCTCTCGCTTGCGGTATCAT & & & \\
\hline$s a b A \mathrm{R}$ & AGCTCAATGTTGTTGGCGTT & 56 & 204 & This study \\
\hline$s a b B \mathrm{~F}$ & GCATTCAAACGGCGAACAAC & & & \\
\hline$s a b B \mathrm{R}$ & TCCTGTGCAGTTCCCATCTT & 56 & 248 & This study \\
\hline $\operatorname{alp} A \mathrm{~F}$ & CGCTCCTATCAAAACCGCTC & & & \\
\hline $\operatorname{alp} A \mathrm{R}$ & TTCCCGTCCAACTTACCGAA & 55 & 185 & This study \\
\hline $\operatorname{alp} B \mathrm{~F}$ & TCAACTTGCGAGCAGACCTA & 57 & 218 & \\
\hline alpB $\mathrm{R}$ & AGCCATAGACCCCATACACG & 57 & 218 & This study \\
\hline oipA F & CTCCACGCTGAAAGGAATGG & 55 & 233 & \\
\hline oipA R & CCATTTCCTGCGAATCGGTT & 55 & 233 & Ihis study \\
\hline
\end{tabular}

*The primers yield a fragment of 229 or 334 bp depending on the presence of a repetitive sequence of 105 nucleotides in some iceA2 alleles [40].

TABle 2: Demographic data of patients in this study.

\begin{tabular}{|c|c|c|c|c|}
\hline & Gastritis & Gastric cancer & Total & $P$ value \\
\hline H. pylori infection (positive/negative) & $23 / 27$ & $11 / 19$ & $34 / 46$ & 0.487 \\
\hline Sex (male/female) & $24 / 26$ & $24 / 6$ & $48 / 32$ & 0.005 \\
\hline Age range $(18-30 / 31-45 / 46-60 / 61-85)$ & $10 / 18 / 17 / 5$ & $0 / 0 / 7 / 23$ & $10 / 18 / 24 / 28$ & 0.000 \\
\hline
\end{tabular}

TABLe 3: Demographic data of the prevalence of $H$. pylori infection among males and females with various age groups.

\begin{tabular}{lccccc}
\hline \multirow{2}{*}{ H. pylori infection } & \multicolumn{2}{c}{ Sex $(n: 80)$} & \multicolumn{3}{c}{ Age group (n: 80) } \\
& Male & Female & $18-30$ & $31-45$ & $46-60$ \\
\hline H. pylori infection (positive, $n: 34)$ & 19 & 15 & 2 & 10 & 11 \\
H. pylori infection (negative, $n: 47)$ & 29 & 17 & 8 & 8 & 11 \\
Total & 48 & 32 & 10 & 18 & 13 \\
\hline
\end{tabular}


TABLE 4: Frequency of $H$. pylori virulence genes' cDNA in biopsy samples of gastric and gastric carcinoma patients with $H$. pylori infection.

\begin{tabular}{|c|c|c|c|c|}
\hline Gene/Disease & $\begin{array}{c}\text { Gastritis, } H \text {. pylori positive } \\
(N=23)\end{array}$ & $\begin{array}{c}\text { Gastric cancer, } H \text {. pylori positive } \\
\qquad(N=11)\end{array}$ & $\begin{array}{l}\text { H. pylori-positive samples }(N=34) \\
(\%)\end{array}$ & $P$ value \\
\hline cagA & $1(4.3 \%)$ & $5(45.5 \%)$ & 17.6 & 0.008 \\
\hline $\begin{array}{l}\text { CagA- } \\
\text { EPIYAC }\end{array}$ & $1(4.3 \%)$ & $4(36.4 \%)$ & 14.7 & 0.029 \\
\hline $\operatorname{cag} T$ & $17(73.9 \%)$ & $11(100 \%)$ & 82.4 & 0.145 \\
\hline $\operatorname{cag} Y$ & $5(21.7 \%)$ & $8(72.7 \%)$ & 38.2 & 0.008 \\
\hline cage & $0(0.0 \%)$ & $5(45.5 \%)$ & 14.7 & 0.002 \\
\hline$v a c A s 1 m 1$ & $7(30.4 \%)$ & $5(45.5 \%)$ & 35.3 & 0.391 \\
\hline$v a c A s 1 m 2$ & $16(69.6 \%)$ & $6(54.5 \%)$ & 64.7 & 0.391 \\
\hline$S a b A / B$ & $15(65.2 \%)$ & $9(81.8 \%)$ & 70.6 & 0.074 \\
\hline$B a b A 2 / B$ & $8(24.8 \%)$ & $7(63.6 \%)$ & 44.1 & 0.469 \\
\hline oipA & $20(87 \%)$ & $11(100 \%)$ & 91.2 & 0.535 \\
\hline$A l p A / B$ & $17(73.9 \%)$ & $10(90.9 \%)$ & 79.4 & 0.552 \\
\hline HopQI/II & $9(39.1 \%)$ & $9(81.8 \%)$ & 42.9 & 0.074 \\
\hline IceA $1 / 2$ & $23(100 \%)$ & $11(100 \%)$ & 100 & 1.000 \\
\hline
\end{tabular}

findings show that simultaneous gene expression in some H. pylori virulence genes could be related to clinical outcomes.

\subsection{Pathological Characters of Gastric Carcinoma Biopsy} Samples. Table 5 shows the frequency of tumor regions in gastric carcinoma patients. The cardia region's frequency was $46.66 \%$ and the highest frequency compared to other tumor regions in gastric carcinoma, including the body, lesser curvature, and antrum regions. Pathology findings showed that out of 30 biopsy samples with gastric carcinoma, 11 cases $(37.5 \%)$ had $H$. pylori infection. These findings were similar to the urea breath test results and H. pylori 16s rRNA molecular detection. The present study results showed no significant difference statistically between gastric carcinoma tumor regions and $H$. pylori infection $(P=0.276)$. The absence of the $a l p A / B$ gene's cDNA in the body tumor region significantly differed from other gastric carcinoma tumor regions $(P=0.024)$. The frequency of $\mathrm{G} 1$, G2, G3, and G4 tumor grades in gastric carcinoma samples were $7(23.33 \%), 14(46.66 \%), 8(26.66 \%)$, and $1(3.33 \%)$, respectively. All cases of $H$. pylori infection were detected in patients with the G1 and G2 tumor stages. $63.63 \%$ of gastric carcinoma tumors with $H$. pylori infection were in the G2 tumor stage $(P=0.047)$. The frequency of oipA, cagT, and ice $A$ genes' $c D N A s$ was similar in gastric carcinoma samples with G1 and G2 tumor grades $(P=0.047)$ (Table 6). This study showed a significant correlation statistically between the frequency of the cagY gene's cDNA and G2 tumor grade in gastric carcinoma samples $(P=0.007)$.

\section{Discussion}

Our study results showed some positive correlations and relationships among transcripts of $H$. pylori virulence genes detected in gastric biopsy samples of gastritis and gastric carcinoma patients with $H$. pylori infection. We surveyed statistical aspects of $H$. pylori virulence genes' cDNA's frequency in gastric biopsy samples and their relationship with clinical outcomes, including gastritis, gastric carcinoma, gastric carcinoma tumor region, and tumor grade. The study was conducted to detect $H$. pylori virulence genes' cDNA frequency, each alone and in combination (Tables 4-6). We surveyed frequency of $H$. pylori adhesin's genes' cDNA that include combination transcripts' cDNA as alp ${ }^{+} /$oip $^{+}$, alp $^{+} /$oip $^{+} / h o p Q^{+}, s a b^{+} / b a b^{+}$, and $a l p^{+} / \operatorname{oip}^{+} / h_{o p} Q^{+} /$ $s a b^{+} / b a b^{+}$and their statistic's correlations with clinical outcomes (Table 7).

Numerous studies have shown the correlation of $H$. pylori vacA $s 1$ and $\operatorname{cag} A$ genotypes with clinical outcomes $[27,40-46]$. On the other hand, some studies have shown the opposite effects of $\operatorname{cag} A$ and $v a c A$ on gastric epithelial cells [46]. Vacuolating cytotoxin A inhibits the production of hummingbird phenotypes in gastric epithelial cells that are created by CagA toxin [46]. The EPEYC motif of CagA protein via stimulating SHP-2 (Src homolog2 domaincontaining tyrosine phosphatase) phosphatase creates needle-like protrusions on the surface of epithelial cells that are called hummingbird phenotypes with a high rate of growth and proliferation rather than normal cells [46]. However, the results of some molecular epidemiology studies show that $\mathrm{cagA}^{+}$strains likely are $\operatorname{vacAs1^{+}}$ genotype simultaneously [46]. Our study results show an inverse correlation coefficient -0.465 (Spearman's static test) between the frequency of vacAs1m2 and cagA genes' cDNA in gastritis gastric carcinoma samples with $H$. pylori infection $(P=0.01)$.

Some studies show that $H$. pylori $c a g A^{+} / v_{\text {acA }} 1^{+} /$babA2 $^{+}$ genotypes significantly correlate with peptic ulcers and gastric cancer [47]. babA gene expression in European strains of $H$. pylori is $40-70 \%$, but in East Asian and American strains, it is $70-100 \%[7,21,43,44]$. There is a high homology between the nucleic acid sequences of 5 and 3 ends of the $b a b A, b a b B$, and $b a b C$ genes, which lead to recombination among these three genes and consequently turn on or off gene expression $[43,48]$. The result of our study showed that the frequency of the $b a b$ gene's cDNA is $63.6 \%$ and $24.8 \%$ in gastric cancer and gastritis biopsy samples with $H$. pylori infection, respectively (Table 4 ). There 
TABLE 5: Frequency of $H$. pylori virulence genes' cDNA in gastric antral biopsy samples of gastric carcinoma patients with stomach tumors in different areas.

\begin{tabular}{|c|c|c|c|c|c|c|}
\hline Variable/Tumor area & $\mathrm{N}(\mathrm{GC})$ & Cardia (N 14) & Body (N 4) & Lesser curvature (N 6) & Antrum (N 6) & $P$ value \\
\hline H. pylori infection & 11 & 3 & 1 & 3 & 4 & 0.276 \\
\hline $\operatorname{cag} A$ & 5 & 1 & 0 & 2 & 2 & 0.662 \\
\hline cagA-EPIYAC & 4 & 0 & 0 & 2 & 2 & 0.284 \\
\hline $\operatorname{cag} T$ & 11 & 3 & 1 & 3 & 4 & 0.276 \\
\hline $\operatorname{cag} Y$ & 8 & 2 & 1 & 2 & 3 & 0.92 \\
\hline $\operatorname{cag} E$ & 5 & 1 & 0 & 2 & 2 & 0.662 \\
\hline $\operatorname{vac} A \operatorname{sim} 1$ & 5 & 0 & 0 & 2 & 3 & 0.260 \\
\hline $\operatorname{vacA} \operatorname{sim} 2$ & 6 & 3 & 1 & 1 & 1 & 0.260 \\
\hline$S a b A / B$ & 9 & 3 & 0 & 3 & 3 & 0.494 \\
\hline$B a b A 2 / B$ & 7 & 2 & 0 & 2 & 3 & 0.810 \\
\hline oipA & 11 & 3 & 1 & 3 & 4 & 0.276 \\
\hline$A l p A / B$ & 10 & 3 & 0 & 3 & 4 & 0.024 \\
\hline HopQI/II & 9 & 2 & 0 & 3 & 4 & 0.156 \\
\hline IceA1/2 & 11 & 3 & 1 & 3 & 4 & 0.458 \\
\hline
\end{tabular}

TABLE 6: Frequency of $H$. pylori virulence genes' cDNA in gastric carcinoma biopsy samples with G1 and G2 tumor grades. All samples with G3 and G4 tumor grades were without $H$. pylori infection.

\begin{tabular}{|c|c|c|c|c|}
\hline Variable/Tumor grade & $\mathrm{N}$ & G1 (N 7) & G2 (N 14) & $P$ value \\
\hline H. pylori infection & 11 & $4(36.36 \%)$ & $7(63.64 \%)$ & 0.047 \\
\hline $\operatorname{cag} A$ & 5 & $1(20 \%)$ & $4(80 \%)$ & 0.303 \\
\hline $\operatorname{cagA-EPIYAC}$ & 4 & $1(25 \%)$ & $3(75 \%)$ & 0.554 \\
\hline $\operatorname{cag} T$ & 11 & $4(36.36 \%)$ & $7(63.64 \%)$ & 0.047 \\
\hline $\operatorname{cag} Y$ & 8 & $1(12.5 \%)$ & $7(87.5 \%)$ & 0.007 \\
\hline cagE & 5 & $1(20 \%)$ & $4(80 \%)$ & 0.303 \\
\hline vacA $\operatorname{sim} 1$ & 5 & $1(20 \%)$ & $4(80 \%)$ & 0.303 \\
\hline$v a c A s 1 m 2$ & 6 & $3(50 \%)$ & $3(50 \%)$ & 0.545 \\
\hline$S a b A / B$ & 9 & $3(33.33 \%)$ & $6(66.67 \%)$ & 0.856 \\
\hline$B a b A 2 / B$ & 7 & $2(28.57 \%)$ & $5(81.43 \%)$ & 0.735 \\
\hline oipA & 11 & $4(36.36 \%)$ & $7(63.64 \%)$ & 0.047 \\
\hline$A l p A / B$ & 10 & $4(40 \%)$ & $6(60 \%)$ & 0.378 \\
\hline HopQI/II & 9 & $4(44.44 \%)$ & $5(53.64 \%)$ & 0.308 \\
\hline Ice A $1 / 2$ & 11 & $4(36.36 \%)$ & $7(63.64 \%)$ & 0.047 \\
\hline
\end{tabular}

TABLE 7: The combined cDNA detected in gastric antral biopsy samples. Some samples had single cDNA that we did not mention. These findings were collected of 23 and 11 gastric antral biopsies in gastritis and gastric cancer samples with $H$. pylori infection, respectively. There were no significant correlations between $H$. pylori virulence genes' cDNA combinations and clinical outcomes $(P>0.05)$.

\begin{tabular}{|c|c|c|c|c|c|}
\hline $\begin{array}{l}\text { alp/oip } \\
\text { (Gastritis/GC) }\end{array}$ & $a l p A+a l p B+o i p A$ & $\operatorname{alp} A+\operatorname{oip} A$ & & & \\
\hline $\begin{array}{l}\text { (Gastritis/GC) } \\
\text { alp/oip/hopQ } \\
\text { (Gastritis/GC) }\end{array}$ & $a l p A+a l p B+o i p A+h o p Q 1$ & $a l p A+o i p A+h o p Q 2$ & $\begin{array}{c}\operatorname{alp} A+\operatorname{oip} A+h o p Q 1 \\
(1 / 0)\end{array}$ & $\begin{array}{c}o i p A+h o p Q 1 \\
(1 / 0)\end{array}$ & \\
\hline $\begin{array}{l}\operatorname{cag} A \\
\text { (Gastritis/GC) }\end{array}$ & $\begin{array}{c}\operatorname{cag} A+\operatorname{cag} T+\operatorname{cag} Y+\operatorname{cag} A- \\
E P I Y A C+\operatorname{cag} E \\
(0 / 4)\end{array}$ & $\begin{array}{c}\operatorname{cag} A+\operatorname{cag} T+\operatorname{cag} Y \\
(1 / 5)\end{array}$ & $\begin{array}{c}\operatorname{cag} A+\operatorname{cag} T+\operatorname{cag} Y+\operatorname{cag} E \\
(0 / 5)\end{array}$ & $\begin{array}{l}\operatorname{cag} A+\operatorname{cag} T \\
(1 / 5)\end{array}$ & $\begin{array}{c}\operatorname{cag} T+\operatorname{cag} Y \\
(5 / 8)\end{array}$ \\
\hline $\begin{array}{l}s a b / b a b \\
\text { (Gastritis/GC) }\end{array}$ & $\begin{array}{c}s a b A+b a b A 2+b a b B \\
(1 / 0) \\
s a b B+b a b A 2 \\
(0 / 2)\end{array}$ & $\begin{array}{c}s a b A+s a b B+b a b B \\
(1 / 0) \\
s a b A+b a b A 2 \\
(4 / 1)\end{array}$ & $\begin{array}{c}s a b A+s a b B+b a b A 2 \\
(0 / 1)\end{array}$ & $\begin{array}{c}s a b B+b a b A 2+b a b B \\
(0 / 1)\end{array}$ & $\begin{array}{c}s a b A+b a b B \\
(2 / 2)\end{array}$ \\
\hline
\end{tabular}

were positive correlation coefficients between the frequency of the $b a b$ gene's cDNA and $\operatorname{cag} A, \operatorname{cag} A-E P I Y A C, s a b$, hopQ, and alp genes' cDNA $(P<0.05)$.

hopQI $I^{+}$genotypes are predominant in East Asia and are associated with $\mathrm{cagA}^{+}$genotypes, whereas hopQII genotypes are predominant in West and Europa and have no association with $\operatorname{cag} A^{+}$genotypes [27, 42]. Some studies have demonstrated HopQ adhesin's effects on the injection and entry of cagA protein into gastric epithelial cells in the company with T4SS [42]. The progress of gastric mucosa 
tissue inflammation increases sialic acid antigens' expression on the gastric epithelial cells [8]. H. pylori is attached to sialic acid antigens by SabA adhesin and lead to a chronic and persistent $H$. pylori infection [8]. H. pylori is attached to gastric epithelial cells by OipA membrane protein in most $H$. pylori clinical strains $[7,25,26]$. The results of some studies show that oipA gene expression is directly related to the expression of $\operatorname{cag} A$ and $v a c A$ genes $[25,26]$. Our study results show that the oipA gene's cDNA's frequency had a positive correlation coefficient of 0.406 with the frequency of the $s a b$ gene's cDNA $(P=0.017)$. Studies show that AlpAB lipoprotein adhesin in $H$. pylori Western strains leads to different cell signaling in gastric epithelial cells than Eastern strains [23]. The study results showed a positive correlation of 0.349 between the frequency of alp $^{+} /$oip $^{+} / h_{o p} Q^{+}$cDNA and gastritis $(P=0.049)$.

As a remarkable result, there was a low frequency of $\operatorname{cag} A$ gene's cDNA in gastric biopsy samples with $H$. pylori infection versus gastric carcinoma biopsy samples $(P=0.008)$. Four samples of the cagA gene's cDNA in gastric carcinoma biopsy samples had an EPIYAC sequence $(P=0.029)$. The cagY and cagE genes' cDNA frequency had a significant difference statistically between gastric biopsy samples with $H$. pylori infection and gastric carcinoma biopsy samples with $H$. pylori infection ( $P=0.008$ and 0.002 , respectively). We compared all frequency of cag pathogenicity island genes' cDNA between two groups of patients with gastritis and gastric cancer in this study (Table 7). The results showed there are positive correlations between cag genotypes and clinical outcomes. The genotypes with transcripts of cagAEPIYAC $C^{+} / \operatorname{cagT}^{+} / \operatorname{cagY}^{+} / \mathrm{cagE}^{+}$had a positive strong correlation of 0.692 with gastric carcinoma $(P=0.005)$. On the other hand, the strains of $H$. pylori without any transcript of cag pathogenicity island genes and $\operatorname{cag} T^{+}$had a low positive correlation of 0.320 with gastritis $(P=0.065)$. Although $H$. pylori did not correlate with clinical outcomes, transcripts of cagY, cagE, oipA, and IceA genes' cDNA had a significant correlation statistically with G2 tumor grade in gastric carcinoma biopsy samples (Table 6). The gastric biopsy samples without any alp gene's cDNA correlated with the body tumor area in gastric carcinoma $(P=0.024)$ (Table 5$)$. The results showed a remarkable difference in $H$. pylori virulence genes' expression between body area tumor and other areas tumor of the stomach. It can be due to differences between the origin and pathophysiology of $H$. pylori infection. In this regard, based on previous studies, most of the gastric cancers in patients with $H$. pylori infection are in the antral and cardia areas [49-51].

To explain the low frequency of some $H$. pylori virulence genes' cDNA in this study, we would say that multiplying control mechanisms reduce gene expression [52-54]. The two-components ArsRS system, which is affected by acidic $\mathrm{pH}$, regulates $H$. pylori genes' expression, including $s a b A$ and cagA [52]. Changing the ORFs direction of cag pathogenicity islands' promotors leads to an unequal gene expression [31, 32]. On the other hand, the molecular mechanisms such as single strand mispairing and the activity of nine types of methyltransferases regulate and limit H. pylori genes' expression.

\section{Conclusion}

The results' statistics analysis shows that some separate and combinatorial transcripts of $H$. pylori virulence genes are related to clinical outcomes.

\section{Data Availability}

The data used to support the findings of this study are included within the article.

\section{Additional Points}

(i) Transcript's profile of $H$. pylori virulence genes, a bacterium with a high level of genetic diversity, is remarkable in clinical strains of gastritis and gastric cancer patients (ii) This study shows a high $H$. pylori strain frequency in gastric antral biopsy samples of gastritis patients without the cagA gene's cDNA to assess cagA gene expression (iii) Evaluation of pathological features of gastric biopsy specimens with Helicobacter pylori infection shows positive correlation coefficients between the frequency of $H$. pylori virulence genes' cDNA and clinical outcomes, including gastritis, gastric adenocarcinoma, tumor grades, and gastric tumor area

\section{Ethical Approval}

The institutional review board has approved the study as no published patients' names were involved in the research project.

\section{Disclosure}

This study results from Doctor Manouchehr Ahmadi Hedayati' (Ph.D. of Medical Bacteriology) thesis.

\section{Conflicts of Interest}

The authors declare that they have no conflicts of interest.

\section{Acknowledgments}

This study was supported and funded by the Kurdistan University Of Medical Sciences by code number IR.MUK.REC.1397/120. The authors thank Sanaz Ahmadi (MSc Medical Microbiology), Doctor Farshad Sheikhesmaeili (Gastroenterologist), Doctor Bahram Nikkhoo (Pathologist), and Doctor Roghayeh Ghadyani (Internal Medicine) for their support in sampling.

\section{References}

[1] S. Odenbreit, "Adherence properties of: impact on pathogenesis and adaptation to the host," International Journal of Medical Microbiology, vol. 295, no. 5, pp. 317-324, 2005.

[2] W.-L. Chang, Y.-C. Yeh, and B.-S. Sheu, "The impacts of $H$. pylori virulence factors on the development of gastroduodenal diseases," Journal of Biomedical Science, vol. 25, no. 1, p. $68,2018$. 
[3] C.-Y. Kao, B.-S. Sheu, and J.-J. Wu, "Helicobacter pylori infection: an overview of bacterial virulence factors and pathogenesis," Biomedical Journal, vol. 39, no. 1, pp. 14-23, 2016.

[4] S. Ansari and Y. Yamaoka, "Helicobacter pylori virulence factors exploiting gastric colonization and its pathogenicity," Toxins, vol. 11, no. 11, p. 677, 2019.

[5] X. Yong, B. Tang, B.-S. Li et al., "Helicobacter pylori virulence factor CagA promotes tumorigenesis of gastric cancer via multiple signaling pathways," Cell Communication and Signaling: CCS, vol. 13, p. 30, 2015.

[6] S. Nagini, "Carcinoma of the stomach: a review of epidemiology, pathogenesis, molecular genetics and chemoprevention," World Journal of Gastrointestinal Oncology, vol. 4, no. 7, pp. 156-169, 2012.

[7] H. Sedaghat, R. Moniri, R. Jamali et al., "Frequency of Helicobacter pylori vacA, cagA, cagE, iceA, babA2, and oipA genotypes in patients with upper gastrointestinal diseases," Iranian Journal of Microbiology, vol. 6, no. 1, pp. 14-21, 2014.

[8] J. Mahdavi, B. Sondén, M. Hurtig et al., "Helicobacter pylori SabA adhesin in persistent infection and chronic inflammation," Science, vol. 297, no. 5581, pp. 573-578, 2002.

[9] D. S. Merrell, M. L. Goodrich, G. Otto, L. S. Tompkins, and S. Falkow, "pH-regulated gene expression of the gastric pathogen Helicobacter pylori," Infection and Immunity, vol. 71, no. 6, pp. 3529-3539, 2003.

[10] S. Gieseler, B. König, W. König, and S. Backert, "Strainspecific expression profiles of virulence genes in Helicobacter pylori during infection of gastric epithelial cells and granulocytes," Microbes and Infection, vol. 7, no. 3, pp. 437-447, 2005.

[11] S. Odenbreit, K. Swoboda, I. Barwig et al., "Outer membrane protein expression profile in Helicobacter pylori clinical isolates," Infection and Immunity, vol. 77, no. 9, pp. 3782-3790, 2009.

[12] J. K. Boonjakuakul, M. Syvanen, A. Suryaprasad, C. L. Bowlus, and J. V. Solnick, "Transcription profile of Helicobacter pylori in the human stomach reflects its physiology in vivo," The Journal of Infectious Diseases, vol. 190, no. 5, pp. 946-956, 2004.

[13] C. R. Raghwan and R. Chowdhury, "Host cell contact induces fur-dependent expression of virulence factors CagA and VacA in Helicobacter pylori," Helicobacter, vol. 19, no. 1, pp. 17-25, 2014.

[14] M. A. La Cruz, M. A. Ares, K. Von Bargen et al., "Gene expression profiling of transcription factors of Helicobacter pylori under different environmental conditions," Frontiers in Microbiology, vol. 8, p. 615, 2017.

[15] L. J. Thompson, D. S. Merrell, B. A. Neilan, H. Mitchell, A. Lee, and S. Falkow, "Gene expression profiling of Helicobacter pylori reveals a growth-phase-dependent switch in virulence gene expression," Infection and Immunity, vol. 71, no. 5, pp. 2643-2655, 2003.

[16] Y. Yamaoka, M. Kita, T. Kodama et al., "Helicobacter pylori infection in mice: role of outer membrane proteins in colonization and inflammation," Gastroenterology, vol. 123, no. 6, pp. 1992-2004, 2002.

[17] T. L. Cover, "Role ofHelicobacter pyloriOuter membrane proteins in gastroduodenal disease," The Journal of Infectious Diseases, vol. 194, no. 10, pp. 1343-1345, 2006.

[18] B.-S. Sheu, H.-B. Yang, Y.-C. Yeh, and J.-J. Wu, "Helicobacter pyloricolonization of the human gastric epithelium: a bug's first step is a novel target for us," Journal of Gastroenterology and Hepatology, vol. 25, no. 1, pp. 26-32, 2010.
[19] S. Talarico, S. E. Whitefield, J. Fero, R. Haas, and N. R. Salama, "Regulation of Helicobacter pylori adherence by gene conversion," Molecular Microbiology, vol. 84, no. 6, pp. 1050-1061, 2012.

[20] M. Oleastro and A. Ménard, "The role of Helicobacter pylori outer membrane proteins in adherence and pathogenesis," Biology, vol. 2, no. 3, pp. 1110-1134, 2013.

[21] F. O. Olfat, Q. Zheng, M. Oleastro et al., "Correlation of the Helicobacter pylori adherence factor BabA with duodenal ulcer disease in four European countries," FEMS Immunology \& Medical Microbiology, vol. 44, no. 2, pp. 151-156, 2005.

[22] Z. Pakbaz, M. H. Shirazi, R. Ranjbar et al., "Frequency of sabA gene in Helicobacter pylori strains isolated from patients in Tehran, Iran," Iranian Red Crescent Medical Journal, vol. 15, no. 9, pp. 767-770, 2013.

[23] R. de Jonge, Z. Durrani, S. G. Rijpkema, E. J. Kuipers, A. H. M. van Vliet, and J. G. Kusters, "Role of the Helicobacter pylori outer-membrane proteins AlpA and AlpB in colonization of the Guinea pig stomach," Journal of Medical Microbiology, vol. 53, no. 5, pp. 375-379, 2004.

[24] A. J. Gutiérrez-Escobar, G. Méndez-Callejas, O. Acevedo, and M. M. Bravo, "Rapid evolution of the Helicobacter pylori AlpA adhesin in a high gastric cancer risk region from Colombia," PeerJ, vol. 6, p. e4846, 2018.

[25] N. Farzi, A. Yadegar, H. A. Aghdaei, Y. Yamaoka, and M. R. Zali, "Genetic diversity and functional analysis of oipA gene in association with other virulence factors among $\mathrm{Hel}$ icobacter pylori isolates from Iranian patients with different gastric diseases," Infection, Genetics and Evolution, vol. 60, pp. 26-34, 2018.

[26] K. Torres, E. Valderrama, M. Sayegh, J. L. Ramírez, and M. A. Chiurillo, "Study of the oipA genetic diversity and EPIYA motif patterns in cagA-positive Helicobacter pylori strains from Venezuelan patients with chronic gastritis," Microbial Pathogenesis, vol. 76, pp. 26-32, 2014.

[27] A. Chichaklu, M. Hedayati, F. Esmaili, E. Ghaderi, and M. Shiri, "Prevalence of hopQ alleles and relationship between cagA and vacA s1 with hopQ I gene in Helicobacter pylori strains isolated from patients with peptic ulcer referred to Towhid hospital in Sanandaj (2014)," Biosciences, Biotechnology Research Asia, vol. 13, no. 1, pp. 91-94, 2016.

[28] Y. N. Srikhanta, R. J. Gorrell, J. A. Steen et al., "Phasevarion mediated epigenetic gene regulation in Helicobacter pylori," PLoS One, vol. 6, no. 12, Article ID e27569, 2011.

[29] K. R. Amilon, D. P. Letley, J. A. Winter, K. Robinson, and J. C. Atherton, "Expression of theHelicobacter pylorivirulence factor vacuolating cytotoxin A ( $\operatorname{vacA}$ ) is influenced by a potential stem-loop structure in the $5^{\prime}$ untranslated region of the transcript," Molecular Microbiology, vol. 98, no. 5, pp. 831-846, 2015.

[30] X.-Y. Yuan, Y. Wang, and M.-Y. Wang, "The type IV secretion system inHelicobacter pylori," Future Microbiology, vol. 13, no. 9, pp. 1041-1054, 2018.

[31] S. Backert, R. Haas, M. Gerhard, and M. Naumann, "The Helicobacter pylori type IV secretion system encoded by the cag pathogenicity island: architecture, function, and signaling," in Type IV Secretion in Gram-Negative and Gram-Positive Bacteria, S. Backert and E. Grohmann, Eds., pp. 187-220, Springer International Publishing, Cham, Switzerland, 2017.

[32] R. M. Barrozo, L. M. Hansen, A. M. Lam et al., "CagY is an immune-sensitive regulator of the Helicobacter pylori type IV secretion system," Gastroenterology, vol. 151, no. 6, pp. 1164-1175, 2016. 
[33] R. A. Aras, W. Fischer, G. I. Perez-Perez et al., "Plasticity of repetitive DNA sequences within a bacterial (type IV) secretion system component," Journal of Experimental Medicine, vol. 198, no. 9, pp. 1349-1360, 2003.

[34] E. C. Skoog, V. A. Morikis, M. E. Martin et al., "CagY-dependent regulation of type IV secretion inHelicobacter pyloriIs associated with alterations in integrin binding," $m B i o$, vol. 9, no. 3, pp. e00717-e00718, 2018.

[35] R. M. Barrozo, C. L. Cooke, L. M. Hansen et al., "Functional plasticity in the type IV secretion system of Helicobacter pylori," PLoS Pathogens, vol. 9, no. 2, Article ID e1003189, 2013.

[36] J. Khatoon, K. N. Prasad, R. Prakash Rai, U. C. Ghoshal, and N. Krishnani, "Association of heterogenicity ofHelicobacter pyloricag pathogenicity island with peptic ulcer diseases and gastric cancer," British Journal of Biomedical Science, vol. 74, no. 3, pp. 121-126, 2017.

[37] K. Baghaei, L. Shokrzadeh, F. Jafari et al., "Determination of Helicobacter pylori virulence by analysis of the cag pathogenicity island isolated from Iranian patients," Digestive and Liver Disease, vol. 41, no. 9, pp. 634-638, 2009.

[38] L. Kennemann, B. Brenneke, S. Andres et al., "In VivoSequence variation in HopZ, a phase-variable outer membrane protein of Helicobacter pylori," Infection and Immunity, vol. 80, no. 12, pp. 4364-4373, 2012.

[39] J. Charan and T. Biswas, "How to calculate sample size for different study designs in medical research?" Indian Journal of Psychological Medicine, vol. 35, no. 2, pp. 121-126, 2013.

[40] J. C. Atherton, P. Cao, R. M. Peek Jr., M. K. R. Tummuru, M. J. Blaser, and T. L. Cover, "Mosaicism in vacuolating cytotoxin alleles of Helicobacter pylori," Journal of Biological Chemistry, vol. 270, no. 30, pp. 17771-17777, 1995.

[41] L. J. van Doorn, C. Figueiredo, R. Sanna et al., "Clinical relevance of the cagA, vacA, and iceA status of Helicobacter pylori," Gastroenterology, vol. 115, no. 1, pp. 58-66, 1998.

[42] L. A. Sicinschi, P. Correa, L. E. Bravo et al., "Non-invasive genotyping of Helicobacter pylori cagA, vacA, and hopQ from asymptomatic children," Helicobacter, vol. 17, no. 2, pp. 96-106, 2012.

[43] R. Mattar, A. F. d. Santos, J. N. Eisig et al., "No correlation of babA2 with vacA and cagA genotypes of Helicobacter pylori and grading of gastritis from peptic ulcer disease patients in Brazil," Helicobacter, vol. 10, no. 6, pp. 601-608, 2005.

[44] C. Chomvarin, W. Namwat, K. Chaicumpar et al., "Prevalence of Helicobacter pylori vacA, cagA, cagE, iceA and babA2 genotypes in Thai dyspeptic patients," International Journal of Infectious Diseases, vol. 12, no. 1, pp. 30-36, 2008.

[45] H. Ogiwara, M. Sugimoto, T. Ohno et al., "Role of deletion located between the intermediate and middle regions of the Helicobacter pylori vacA gene in cases of gastroduodenal diseases," Journal of Clinical Microbiology, vol. 47, no. 11, pp. 3493-3500, 2009.

[46] D. R. Bridge and D. S. Merrell, "Polymorphism in the Helicobacter pylori CagA and VacA toxins and disease," Gut Microbes, vol. 4, no. 2, pp. 101-117, 2013.

[47] H. Dabiri, F. Jafari, K. Baghaei et al., "Prevalence of Helicobacter pylori vacA, cagA, cagE, oipA, iceA, babA2 and babB genotypes in Iranian dyspeptic patients," Microbial Pathogenesis, vol. 105, pp. 226-230, 2017.

[48] S. Ansari and Y. Yamaoka, "Helicobacter pyloriBabA in adaptation for gastric colonization," World Journal of Gastroenterology, vol. 23, no. 23, pp. 4158-4169, 2017.

[49] N. Amoori, S. Mahdavi, and M. Enayatrad, "Epidemiology and trend of stomach cancer mortality in Iran," International
Journal of Epidemiologic Research, vol. 3, no. 3, pp. 268-275, 2016.

[50] M. J. Blaser and J. C. Atherton, "Helicobacter pylori persistence: biology and disease," Journal of Clinical Investigation, vol. 113, no. 3, pp. 321-333, 2004.

[51] L. Saragoni, P. Morgagni, A. Gardini et al., "Early gastric cancer: diagnosis, staging, and clinical impact. Evaluation of 530 patients. New elements for an updated definition and classification," Gastric Cancer, vol. 16, no. 4, pp. 549-554, 2013.

[52] D. Beier and R. Frank, "Molecular characterization of twocomponent systems of Helicobacter pylori," Journal of Bacteriology, vol. 182, no. 8, pp. 2068-2076, 2000.

[53] M. Pflock, N. Finsterer, B. Joseph, H. Mollenkopf, T. F. Meyer, and D. Beier, "Characterization of the ArsRS regulon of Helicobacter pylori, involved in acid adaptation," Journal of Bacteriology, vol. 188, no. 10, pp. 3449-3462, 2006.

[54] J. C. Atherton and M. J. Blaser, "Coadaptation of Helicobacter pylori and humans: ancient history, modern implications," Journal of Clinical Investigation, vol. 119, no. 9, pp. 24752487, 2009. 